\title{
Islamic Education Management perspective of Noah AS
}

\author{
Bachtiar Hariyadi \\ Universitas Sunan Giri Surabaya \\ schoolbook68@gmail.com
}

\begin{abstract}
:
This study aims to explain the implementation of the wisdom of Idariyah in the management of Islamic education. This research is a literature study. Data collection methods used are studies taken from books that discuss Noah and management of Islamic education. The results of this study are Islamic education is an organization based on the Qur'an and the hadith of the Prophet, so the management must be absolutely perfect in all aspects. Noah was a model of an outstanding leader in dealing with the problems of his people, firmly defending the truth, never giving up and not caring about demons who discouraged his preaching. His perseverance and determination must be set as an example by today's leaders.
\end{abstract}

Keyword: Idariyah, Islamic Education Management, Noah As

\section{INTRODUCTION}

Muslims are required to believe in the existence of the apostles as role models and role models in living this life. Various stories of the prophet are in God's words for us to study and we practice so that we can save the world and the hereafter. As an example in life, one of the stories of the prophet that we can make an example of is the prophet Noah As. Who has the features of Allah SWT. Noah himself is the 9th descendant of Prophet Adam. the distance between Noah and Adam was 10 centuries. The religion of Islam brought by the Prophet Adam continued to develop, but after a long period between the prophet Idris and the Prophet Noah, causing humanity, namely the Noah who existed at that time, had gone very far from the path of God. They returned to the act of disbelief by worshiping statues which they considered to be gods. They imitate their fathers beforehand and assume that the action must be true. The statues were originally pious people who were the heirs of the Prophet Idris, who preached so that Islam is always practiced by the community. The pious people called wadd, shuwa always remind people to fear Allah SWT. However, when these pious people died the devil of la'natullah began to whisper the ancestors of Noah not to forget their services. The way to not forget their services is to make statues that resemble those pious people. In the early days of making this statue, the faith and Islamic community were still maintained. But over time and after several generations, when religious knowledge began to fade between them, the devil slowly but surely began to lead the people of Noah to worship these statues and make him God. That is how the devil's cunning way of deceiving mankind. The 
devil again succeeded in making the descendants of Adam again tempted to persuade them. The Noah then became very far astray in obedience to God. Faith and worship to Allah they do not know anymore. And the devil also became very happy, because he had succeeded in inviting humans to accompany him to be a denizen of Hell.

From the description above, Noah, who was still willing to use his common sense, could think and eliminate this helplessness and make him free from all forms of identity of his people, and break away from worship to these man-made statues. Allah SWT then raised Noah as the successor to the prophetic treatise. The struggle of Noah is what we will take the idolohnya and wisdom contained in it as a lesson. In Islamic education management, hard struggle and strong command and reliable managers are needed so that an institution will develop rapidly. The wisdom contained in the story of the prophet Noah will be taken by his management function in his leadership and his toughness in maintaining the religion of Allah SWT.

\section{METHOD}

Based on the type of data the research conducted is the type of literature review research (literature review). Some of the literature used in literature study can be found from the names mentioned

\section{RESULTS AND DISCUSSION}

\section{The Story of Noah AS}

For centuries, the age of the Prophet Idris AS passed and humans deviated a lot from the moral teachings and creeds brought by the prophet Adam, Allah sent a prophet named prophet Noah AS He is the ninth descendant of Adam, his father is lamik bin metusyalih bin idris. Suyuti said that the true name of the prophet Noah was Abdul Ghaffar, because of the frequent weeping, Noah was given the name. He was appointed as a prophet and apostle when he was 480 years old, he carried out his mission for five centuries and died when he was 950 years old, Noah, "The Story of Noah As According to the Qur'an," Jurnal Al-'Adl Vol 6, no. 1 (2013).Noah AS, known as a prophet who is fluent in speaking wisely and patiently. In carrying out his treatise, even though he had preached with all his might using his skills, wisdom, and patience even though the time of carrying out his mission was very long, Noah AS only got followers between 70 to 80 person. And even then only among the weak.(Anshori, 2015)

According to the Koran, he has 4 sons namely Kan an, Sem, and Yafet. But the Bible only records that Noah had 3 sons, Shem, Ham, and Japheth. From Ibn Kathir, that Noah was sent to the people of the rasib, he was born 126 after the prophet Adam AS.(Anwar, 2017) Besides that the community of Noah was divided into various layers of society, there were those who had wealth and fields, and there were those 
who were good at farming and carpentry. They are arrogant and forget the land, based on these conditions, the task of Noah the US through his da'wah is very much of which is to restore monotheism in terms of divinity and eliminate shirk and worship. abolishing the arrogant nature and social classes. And reject the accusations that are always leveled at him.

While the method of preaching Noah As from the point of content or content of preaching, the prophet Noah tried to restore monotheism and reminded of the Hereafter, in connection with that Allah explained in the Koran means:

Noah said: "O my Lord Behold I have called my people night and day, Then my cry was only to add them to flee (from the truth) and Verily Every time I call on them (to faith) that You forgive them a, they put their finger in his ear and cover his shirt (his head) and they keep (deny) and boast very, then I have called them (to the faith) in a blatant manner [1517], and indeed I am (calling) to them (again) openly and quietly [1518], Then I say to them: 'Ask forgiveness from your Lord, -he is the Most Forgiving,

Verily we have sent Noah to his people, then he said: 0 my people, worship Allah, there is no god for you except him, verily (if you do not worship) I am afraid that you will be struck by the punishment of a great day (the Day of Judgment).[2](Nur, 2014) Noah AS also reminded people about God who created everything that is omnipotent and reminded them with the pleasure of giving. He invited the people to see this nature, just as there is a self-superior nature (cosmos), plants or etcetera and think about it to be associated with God as the almighty creator.

Convincing him, especially to the community that he was the messenger of Allah swt. Noah conveyed his teachings of God in a quiet (quiet) and open depending on the circumstances, or follow the needs of the situation, without knowing bored and tired, he tried day and night, all actions community opposition horn does not occasionally fade his enthusiasm to preach, he continues to try to change the Uslub to attract them.(Anton Afrizal, 2017) Noah continued to try to convince his people and remind the punishment that would be received if they did not follow his call.

Noah continued to preach and invite his people who are biased towards this teaching and assured that he Allah was chosen as the apostle for his people, this is stated in the word of God Almighty, I am an apostle of trust (sent) to you, so fear Allah and obey me, and I will never ask for your reward from those invitations; my reward is none other than the Lord of the worlds h to Allah and obey me. (QS. AsySyuara ': 107-110)

And indeed We have sent Noah to his people. Then he said, "O my people, worship by Allah, because there is no God for you but Him. Then why are you not cautious (of Him)? (QS. Al-Mukminun: 23) (Abdul Ghafar Don, 2011) The many people who could not accept Noah and denied Noah's invitation made him anxious and tried to remind his people that Allah would curse their behavior who did not want to worship Allah 
theremembrance of Noah to his people to Avoid Punishment from God, because God's punishment is very painful.

\section{Leadership in Making the Ark}

In the order that required to make a big boat because of the great flood that made Noah more distant from his people, because he was considered a big liar. But with a strong determination for this decision the prophet Noah never surrendered, Imagine also how difficult it is to make a big ship in a depressed and hostile atmosphere of the people who disobeyed and disobeyed him, but the Prophet Noah remained convinced of the vision of saving this civilization and still led his followers to finish such a big task. Without tiring, motivating each other and remaining confident of the dissidents who always mocked him, Noah and his followers could finish the rescue boat. After that, the Prophet Noah and his followers put many types of animals into the pair. Finally, the Noah's Ark sailed safely on the fierce waves. This is explained in the Qur'an Surah Al Hud, 11 verses 37-40: Meaning : $\quad 37$ and make the ark with the supervision and guidance of our revelation, and do not talk with me about the wrongdoers; Surely they will be drowned. and Noah began to make the ark. and Every time the leader of his people walked through Noah, they mocked him. said Noah: "If you mock us, then surely we (even) mock you as you mock (us). 39. later you will know who will befall the doom that humiliates him and what will befall eternal doom." 40. until when our command comes and the kitchen [718] has emitted water, We say: "Load it in the ark from each pair of animals (male and female), and your family except for those who have predetermined them and (include them) believers. " and do not believe with Noah except a little.

\section{The Lawlessness of the Family of Noah}

The people who believed and believed were not many, even his family did not follow his call. Noah Alaihissalam was blessed with four descendants. His oldest son was named Kan'an and his younger siblings were named Yafith, Sam and Ham. Before the punishment of Noah, Kan'an hid his hatred of his father and pretended to believe. Then one day the nnur began to show its signs from inside the house of Noah. Knowing that, the Prophet Noah immediately opened his ark and invited the believers to ride it. Gabriel came down to earth. Noah brought birds, wild animals, paired animals, cows, elephants, ants, and others. Gabriel herded every two animals in pairs so that each animal species did not go extinct from the face of the earth. According to history the first animal to ride was an old parrot, while the last animal was a donkey, it was told that the devil was hanging on the shoulder of the donkey. (Supriadi, 2002)

Noah's wife did not believe in him so he did not join in the boat, and one of his children, Kan'an also did not believe. There are only 80 believers who enter the ark. 
The land animals of Allah gather on the first floor of the ship, while the second floor of humans, and the third floor of bird species. So that wild animals do not prey on tame animals, then Allah sends down fever to these wild animals. After all the creatures that Allah has ordained survived entered the ship and the door of the ship was closed then with His power, Allah sent water from the sky and water from the earth. Water begins to rise which comes out of the cracks of the earth. There is not a single crack on the earth except water comes out of it. Besides that, from the direction of the sky there also began to rain, which was so heavy and unprecedented, that it was so heavy on earth, including afterwards there would be no more rain like that. The ocean is increasingly turbulent and the waves hit anything and sweep the earth (Noah, 2013).

But when Azab arrived and a great flood surrounded all parts of the earth, Kan'an's iniquity was seen. God dismantled his hypocrisy and did not include him in the group of survivors, so that when Noah's ark began to sail, Kan'an, the son of Noah Alaihissalam, did not want to enter the ship and still wanted to save himself by swimming to the top of a mountain that had not been touched by water. Kan'an believes that water cannot reach the top of the mountain. When all the water has covered the earth, a father's instincts of love emerge that finally makes Noah As with all his efforts try to invite, to persuade and seduce Kan'an, his son to be willing to come with him ride the ark. "Kan'an my child! Get on the boat with us! Do not die together with unbelievers! " Kan'an answers? "No, Daddy! I will be safe at the top of the mountain. " Said Kan'an pongah "Kan'an .... listen to Daddy! There is no one who can protect you from this condition except Allah, the Most Merciful. (Surah Hud: 4243 Interrupted by the conversation between the father and son, suddenly a big wave appeared to obstruct the two. Kan'an immediately vanished from the vision of Noah As. Noah As was trying to find, but He could not find other than the waves that the higher the Prophet Noah As was very sad, he had lost his beloved child, there was no surface of the earth left, all of it had sunk so that there were no more living humans except those on the boat. Noah was very sad and regretted the death of his son tragic, he regretted that Kan'an did not follow his invitation Noah wondered why Allah did not save his son, even though Noah had seen Kan'an not seem to refute his words, apparently NAbi Noah had not realized that Kan'an had been hiding his disbelief. Noah, who was very sad at that time, unconsciously said, from his oral plea, "O my Lord, in fact my child is including my family and sesun the promise of thee is true. And You are the fairest Judge ". (Surah Hud: 45) Allah SWT also explained to the Prophet Noah Alaihissalam, "Hi Noah, actually Kan'an is not included in your family who was promised to be saved. Actually his actions were not good. Therefore, do not ask me for something that you do not know its essence. I warn you that you should not be among those who are not knowledgeable ". (Surah Hud: 46 
The bowels of the earth are turbulent and move with an unprecedented movement, it is not natural to cause the globe to sink in water for the first time, and the earth becomes like a ball of water, Meaning: 41. and Noah said:" Go up all ofyou in the name of God when sailing and anchoring. "Verily, my Lord is truly Forgiving, Most Merciful.42. and the ark sailed them in waves like a mountain. and Noah called out to his son, [719] while the child was in a remote place: "O my son, go up (with the ship) with Us and do not be with those who disbelieve." 43. his son replied: "I will seek refuge in a mountain that can keep me from the flood!" Noah said: "There is nothing to protect today from the punishment of Allah except Allah (only) the Most Merciful". and waves become a barrier between the two; Then be a child including those who drowned.44. and it was said: "O earth, swallow your waters, and $O$ heavens (rain) stop," and water was choked, orders were completed [720] and the ark was anchored on the hill of Judi [721], and it was said: "The sufferings of the wrongdoers. "45. and Noah cried out to his Lord, saying: "O my Lord, indeed my son is including my family, and verily your promise is true, and you are the fairest judge."

Many people in this age are easily stressed when overwritten by problems, challenges, and obstacles that happen to them in their daily lives. It turns out that they are people who do not communicate the problems they face to others until the problems accumulate in each of them. Noah exemplified us that to be free from the pressures of problems, other human clamps and feelings of defeat, he did not complain to humans but directly complained to God, the King of humans. He was afraid and not sad in the face of obstacles and obstacles, but he prayed, complained, and called on God so that finally God won his struggle.

This is contained in the Qur'an Surah Al Mu'minun, 23 verse 26: "He (Noah) prayed," 0 my Lord, help me, because they reject me It means: and actually we have: and actually. sent Moses by bringing our verses and tangible information, 24. to Fir'awn, Haman and Qarun, so they said: "(He) is a liar and a liar".25. So when Moses came to them they brought the truth from our side they say: "Kill the children of those who believe with him and leave their women alive" and the deception of the people o rang kafir is nothing but a waste (mere).

The water continues to rise high above the heads of humans, even to the height of trees, and mountain tops. Finally, the entire surface of the earth is covered with water. That's the biggest and biggest flood and tsunami of all time. There is no flood of this size again until the end of the world comes later. (Harahap, Prasojo, Nasihin, \& Setia, 2016)Floods, typhoons and tsunamis hit all parts of the earth. There is no part of the earth that does not sink. One history describes the earth like a water ball. All living things, plants, animals and humans are destroyed, nothing is left. After 150 days adrift above the sea without limits, finally Allah Almighty also gave the order for the water to recede. After the water receded, Noah's ark landed safely on the 
Armenian Judd hill. The prophet Noah and his followers came out of the ark. About 80 people who took part in the ark of Noah along with the three children of Noah descended. They with animals that survived began their new lives(Noah, 2013).

It is narrated that all the followers of Noah who joined together in Noah's ark would die without leaving even one descendant. Only the son of Noah, Sam, Ham and Yafith, had children. Until finally all human races that exist today are all descendants of the three of them. It is not surprising then that Noah was also referred to as the father of men. Sam and his descendants were the forerunners of the Arabs, Yafith gave birth to Roman (Roman) descendants and Ham produced descendants of the Habassah (Ethiopia). (Nur, 2014)

The hope of Idariyah is that it is hoped that it can provide a source of learning as well as strengthening our faith and enthusiasm in practicing Islam in life. We have understood that the Qur'an is a book that is 1,400 years old. Muslims believe that this book was revealed by God, the Creator of Heaven and Earth, Allah. Allah is an Arabic word for God. One God, the Creator, the All-Knowing, the All-Wise. So it is not surprising to us as Muslims that the Qur'an must be accurate and consistent because it is revealed by the All-Knowing, the All-Wise. So of course it's normal, normal for us, we believe this book is an accurate and consistent book. But for some people today, and many people claim they don't believe in God, or they don't believe that God sends us instructions and revelations. This remains a challenge for you and remains a great sign, a proof that makes every Muslim increasingly certain and become more faithful that the Koran is indeed a revelation from the Almighty, the All-Wise.

The Qur'an about the great Prophet of God called Noah. And Noah is certainly also told in the Bible. I'm sure you all know the story of Noah, how God sent Noah to his people. 7 The people of Noah refused to believe in Him and because of that God sent floods to them. Before the flood, God told Noah to build an ark. And it is very interesting that recent archeological research around the area of Mount Judi, which in fact there is indeed a mountain named Judi in Turkey today. And at the mouth of Mount Judi, there is a boat-shaped object with the same size as Noah's ark. While the Bible states that the ark is stranded on Mount Ararat which is actually 20 miles away from Mount Judi. And there are some problems with images in the Bible (Anshori, 2015). The first problem is that the Ararat mountains are a relatively new geological formation.

Even the Koran only refers to the punishment given to Noah and his people, as something special for Noah and his people. So even though we don't have geological evidence for universal disasters, of course we have a lot of geological evidence that there is massive flooding in that area alone. boat and research has been done there, that the object is the remains of a large boat. And where was he found? On Mount 
Judi as the Qur'an says. As for those who seek the ark on Mount Ararat, people have been searching for it in vain for years and have found nothing.

\section{function of islamic education management}

Islamic education is an organization based on the Qur'an and the hadith of the Prophet, so its management must be absolutely perfect in all aspects. Noah was a model of an outstanding leader in dealing with the problems of his people, firmly defending the truth, never giving up and not caring about demons who discouraged his preaching. His perseverance and determination must be exemplified by today's leaders. An ark that could not possibly be made came true by the hard work of his people under his command. If an institution has such a charisma of a leader and such a management system will certainly be an extraordinary institution.

Obedience in this story is manifested in instilling love and respect for the Koran, relating to it, reading well, understanding and practicing its teachings. Fostering pride in the history and culture of Islam and its heroes and following in their footsteps. Cultivate a sense of willingness, optimism, confidence, responsibility, respect for obligations, please help with goodness and piety, compassion, love of kindness, patience, struggle for good, uphold principles, sacrifice for religion and homeland, and be ready to defend it. Instill strong faith in God in themselves, strengthen religious feelings, nourish their hearts with love, remembrance and piety to Allah. Clean their hearts from envy, envy, hatred, cruelty, selfishness, selfishness, deception, treason, nifaq, doubt, division and disputes.

Many leaders at this time are easily stressed when overwritten by problems, challenges, and obstacles that occur in everyday life. It turns out that they are people who do not communicate the problems they face to others until the problems accumulate in each of them. Noah exemplified us that to be free from the pressures of problems, other human clamps and feelings of defeat, he did not complain to humans but directly complained to God, the King of humans. He was afraid and not sad in the face of obstacles and obstacles, but he prayed, complained, and called on God so that finally God won his struggle.

\section{CONCLUSION}

Al-Qur'an tells a lot of stories of the life journey of the prophets including the story in the Qur'an about the great Prophet of God called Noah. How God sent Noah to his people. 7 The people of Noah refused to believe in Him and because of that God sent floods to them. Before the flood, God told Noah to build an ark. And it's exciting to go up because of the big flood. All believers ride it. and there was a flash flood that drowned the earth.

Islamic education is an organization based on the Qur'an and the hadith of the Prophet, so its management must be absolutely perfect in all aspects. Noah was a 
model of an outstanding leader in dealing with the problems of his people, firmly defending the truth, never giving up and not caring about demons who discouraged his preaching. His perseverance and determination must be exemplified by today's leaders. Noah exemplified us that to be free from the pressures of problems, other human clamps and feelings of defeat, he did not complain to humans but directly complained to God, the King of humans. He was afraid and not sad in the face of obstacles and obstacles, but he prayed, complained, and called on God so that finally God won his struggle

\section{REFERENCES}

Abdul Ghafar Don, N. N. H. \& R. M. @ K. 2011. Dakwah Kepada Non-Muslim : Sorotan Pendekatan Rasul Ulu al- Azmi. Jurnal Islamiyyat, 33, 45-52.

Anshori, A. (2015). Ideologi Syi'ah: Penelusuran Sejarah. Asy-Syir'ah: Jurnal Ilmu Syari'ah Dan Hukum.

Anton Afrizal, C. 2017. Pemikiran Siyasah Syar'iyah Ibnu Taimiyah (Kajian Terhadap Konsep Imamah Dan Khilafah Dalam Sistem Pemerintahan Islam). UIR Law Review, $1(02)$, 161-172. https://doi.org/https://doi.org/10.25299/uirlrev.2017.1.02.956

Anwar, A. 2017. Tipe kepemimpinan profetik konsep dan implementasinya dalam kepemimpinan di perpustakaan. Pustakaloka, 9(1), 69-82.

Harahap, G., Prasojo, W. B., Nasihin, A., \& Setia, K. 2016. Nilai-Nilai Pendidikan Islam: Kisah Nabi Nuh AS dan Kaumnya. Fikiran Masyarakat, 4(1), 50-79.

Nuh, N. 2013. KISAH NABI NUH AS MENURUT ALQURAN. Jurnal Al-'Adl Vol, 6(1).

Nur, A. 2014. Dekonstruksi Isra'Iliyyat Dalam Tafsir Al-Mishbah. Anida', 39(1), 3648.

Supriadi, A. N. 2002. Kisah Nabi Musa Dalam Al-Qur'an (Studi Perbandingan Tafsir Al-Kasya> f Dan Ru> h Al-Ma'a>ni>). Skripsi Fakultas Ushuluddin IAIN Sunan Kalijaga, Yogyakarta. 